\title{
OPHTHALMOLOGY IN AUSTRALIA
}

THE Ninth Annual Congress of the Ophthalmological Society of Australia (B.M.A.) was held at B.M.A. Hall in Melbourne from October 3 to 7 under the presidency of Dr. Arthur Joyce. Abstracts of the papers will in due course appear in Ophthalmic Literature, but meanwhile the organisers of the Congress are to be congratulated upon their achievement. Dr. A. L. Lance (Sydney), the Honorary Secretary of the Society, had collaborated so efficiently with the local Honorary Secretaries of the Congress, Dr. Esmé Anderson and Dr. S. R. Gerstman of Melbourne, that all the arrangements worked smoothly, and success was finally clinched by the atmosphere of free, informal discussion communicated by the President.

At the opening session members were gratified to hear a message of greeting from Sir John Parsons, a confirmed admirer of Australian scientific talent. Among the contributors to the scientific programme were Dr. Ronald Lowe (Melbourne) and Dr. Hugh Ryan (Melbourne), whose energetic work at the Institute of Ophthalmology and elsewhere in London is fresh in the memory of English ophthalmologists. Another junior ophthalmologist, Dr. K. B. Redmond (Orange), gave a carefully prepared paper on the causation and prevention of blindness. Dr. Kevin O'Day's (Melbourne) discourse on iris tumours was illustrated by exçellent microphotographs, and Dr. J. Ringland Anderson (Melbourne) was as stimulating as ever. There were also interesting communications from Dr. J. Bruce Hamilton (Hobart), Dr. Norman Macindoe (Sydney), Dr. G. A. Brew (Melbourne), Dr. J. L. R. Carter (Launceston) and Dr. D. T. Shortridge (Warrawee).

Miss Ida Mann spoke about the movement of macrophages in corneal grafts. She also gave an illustrated account of the Institute of Ophthalmology in London, and showed a film recording her former visit to Australia. A paper in which Mr. Frank Law, President of the Faculty of Ophthalmologists, had recorded his unofficial impressions about ophthalmology under the National Health Service was read out by Mr. J. H. Doggart, Mr. Doggart and Mr. T. Keith Lyle each gave two other talks. One of the afternoons was devoted to a clinical meeting at the Eye and Ear Hospital, where a rich array of material had been assembled, Discussion of the cases followed under the chairmanship of Dr. Walter Gibson (Brisbane). Honorary membership of the Society was conferred upon Mr. J. H. Doggart and Mr. T. Keith Lyle, who expressed to the President their warm appreciation of this honour. It will be recalled that Miss Ida Mann was similarly honoured on the occasion of her previous visit to Australia.

The present writer retains vivid memories of hospitality generously 
dispensed by the President and Mrs. Arthur Joyce, Dr. and Mrs. J. Ringland Anderson, Dr. and Mrs. W. Box, Dr. and Mŕr. Kevin O'Day, Dr. and Mrs, Mark Gardner, Dr. Esmé Anderson and many others, including the Council of the Australasian College of Surgeons. He will never forget also the expedition to Warrandyte, where Dr. and Mrs. Edward Gault entertained a number of congressists shepherded by his daughter and colleague, Dr. Adelaide Gault. Although Dr. Edward Gault is well into the ninth decade of life, he stood up as straight as a lance, to make his speech at the Annual Dinner. It was at this same banquet that Dr. Archie Anderson (Melbourne) made his memorable mot: "Ida came out to us ten years ago, every inch a Mann; and now she's come back a regular Gye."

A medical man who spent several years in Australia described its people as the most hospitable in the world. Certainly nothing could have been kinder than the welcome accorded to the guest speakers from England. Nothing was left undone to promote their enjoyment and to put them at ease in this glorious city, and so the memory of their visit to Melbourne is exceedingly precious-and all the more so, by reason of the enthusiasm with which the coming generation is attacking ophthalmological problems on the continent of Australia.

\section{TASMANIA}

On October 12 a meeting of the Tasmanian Section of the Ophthalmological Society of Australia was held at the Royal Society's room in the Tasmanian museum at Hobart. Mr. J. H. Doggart spoke on retinopathy in the diabetic, and $\mathrm{Mr}$. T. Keith Lyle's subject was traumatic surgery of the face. The chair was occupied by Dr. J. Bruce Hamilton, to whom these visitors are deeply indebted for a multitude of reasons. Not only were they hospitably entertained in the home of Dr. and Mrs. Bruce Hámilton, but they were also shown the apple-blossom of the Huon riverside and introduced to a multitude of other delightful friends, including Dr. and Mrs. Alec Budge, who met them on arrival at Wynyard and made them so welcome at Devonport. Dr. and Mrs. Tim Palfreyman were also in the vanguard of those who loaded us with kindness, and other delightful hosts were Dr. and Mrs. J. L. R. Carter, Dr. and Mrs. D. H. Waterworth, Dr. T. G. H. Hogg (a nephew of Mr. Rupert Scott) and Dr. J. L. Grove. Hobart and Launceston seem to be full of warm-hearted people, and Tasmania might well be described as a series of enchanting landscapes.

\section{New Zealand}

The Annual Congress of the Ophthalmological Society of New Zealand took place last May, but a special conference, to which the visiting speakers at the Australian Congress were invited, was held 
at Christchurch on October 26 and 27. Miss Ida Mann was unable to attend, though she hopes to re-visit New Zealand in the near future. The President of this gathering was Dr. W. H. Simpson (Wellington), a former Moorfields House Surgeon, whose son, now settled in Vancouver, recently occupied the same post. Dr. Simpson is remarkable for his lively wit and geniality of presence, so that the success of the meeting was virtually certain from the outset. Dr. W. J. Hope-Robertson (Wellington), the Honorary SecretaryTreasurer of this young and vigorous Society, is to be congratulated upon his organising zeal, and great credit is also due to Dr. Harry Wales, the local Honorary Secretary, and to Dr. Lindsay Burns, also of Christchurch. The wives of these four ophthalmologists all played a prominent part in the social side of the meeting.

Mr. J. H. Doggart and Mr. T. Keith Lyle each contributed three papers, and an interesting group of clinical cases was discussed under the chairmanship of Dr. Lindsay Burns, a former Moorfields House Surgeon. A fascinating talk on artificial eyes in ancient Egypt was given by Dr. Rowland Wilson, whose distinguished work at the Giza Memorial Laboratory is known throughout the world of ophthalmology. The width of Dr. Wilson's clinical and scientific interest is remarkable, so that he is able to make stimulating queries and fruitful suggestions about almost every conceivable subject. Certainly he exerted a strong fertilising influence during the discussions which followed the papers.

Before the Christchurch meetings, Mr. Doggart and Mr. Lyle were entertained by the Auckland ophthalmologists at a dinner over which Dr. W. A. Fairclough presided. Dr. H. V. Coverdale, Dr. Graeme Talbot, Dr. Calvin Ring and a number of other old friends were present at what proved to be a most successful evening's entertainment. Here and elsewhere in New $Z$ ealand it was a special joy to see former colleagues and house surgeons happily settled, and carrying on with the excellent work which we had learned to expect from them by reason of their former activities in Great Britain. $\mathrm{Mr}$. Lyle snatched a few days away from the preparation of his discourses, and took Mrs. Lyle to browse on the beaches of North Island, and to career over the roads in a car lent by his former house surgeon, Dr. Charles Swanston. Mr. Doggart was generously welcomed at Dunedin by Sir Charles Hercus, the Dean of the Medical School of Otago University, and gave a talk to the students. He was hospitably entertained by Dr. and Mrs. Rowland Wilson, and was also enabled by Dr. Wilson to see something of the work of that enterprising cranio-surgeon, Dr. Murray Falconer. Mr. Doggart also visited Dr. Ryburn at Knox House, under the wing of Dr. John Stewart, and afterwards the latter's father, Dr. Garfield Stewart (Auckland), conducted Mr. Doggart to Queenstown, where 
he watched the sun rise over Lake Wakatipu, and revelled in the splendour of Milford Sound. . Dr. and Mrs. John Doctor regaled the visitors at their-charming Waikanae home, and Mrs. Garfield Stewart once again proved herself to be a wonderful hostess in Auckland.

New Zealand is a land of infinite variety, and it is curious to think how few miles intervene between the austere peaks of the Southern Alps, and the lambs that frolic over the Canterbury plains. Christchurch, whose winding river and green grass recall the quietude of Cambridge and Salisbury, conveys an atmosphere. altogether different from that of Dunedin, Wellington and Auckland, but one feature is common to all the cities of New Zealand-a kindly welcome to friends from across the sea.

\section{ADELAIDE AND SYDNEY}

Miss Mann and her husband, Professor W. E. Gye, called at Adelaide during their sea voyage to Melbourne, and were welcomed by Dr. and Mrs. A. L. Tostevin, who also lavished hospitality on Mr. Doggart before the Melbourne conference. Mr. Doggart visited the Adelaide Children's Hospital under the guidance of Dr. Geoffrey Barham Black and Dr. D. O. Crompton. On October 14 a number of interesting cases were discussed at a clinical meeting preceded by a dinner to which Dr. Tostevin had bidden his Adelaide colleagues and his visitor. To the writer of this article it was a memorable experience to bestride the Oval cricket ground, to sail across the inner harbour, and to hear the twanging of innumerable frogs intermingled with the kookaburra bird's chatter: The inhabitants of Adelaide have good reason to revere the memory of Colonel Light, whose forethought andidetermination are mirrored in the layout of this lovely city.

Mr. and Mrs. T. Keith Lyle, who travelled via Vancouver, reached Sydney on September 25 and were followed two days later by $\mathrm{Mr}$. J. H. Doggart. They spent a few days there before the Melbourne meetings, another day or two before going to New Zealand, and again nearly a week before the final departure on November 4. With Dr. V. M. Coppleson in the chair, the New South Wales representatives of the Royal Australasian College of Surgeons generously entertained Mr. Doggart and Mr. Lyle to dinner at the Australian Club on October 31, and afterwards the visitors each. contributed a paper in the lecture hall of the College of Physicians. Dr. Stephen Lynch, who formerly worked at King's College Hospital with Mr. H. Willoughby Lyle, crowned the evening with a rousing welcome by Mrs. Lynch and himself at their beautiful Vaucluse home.

Mr. Lyle also addressed the New South Wales Ophthalmological 
Society on November 2-a meeting which Mr. Doggart was unable to attend, because he was basking in the hospitality of Dr. and Mrs. Cliftord Colvin at Orange. One of Mr. Doggart's most stimulating experiences was a visit to Dr. Mervyn Archdall at the editorial headquarters of the Medical Journal of Australia. It is seldom realised in England that Printing House, Seamer Street, not only produces that magnificent Journal, but also issues an abundant jet of other periodicals, text-books, works of reference, etc. It was a great privilege to meet the manager, $\mathrm{Mr}$. Noldt, and many other members of Dr. Archdall's happy team of colleagues. This beloved editor was one of the most popular figures at the Melbourne congress, and he was also a guest at Dr. and Mrs. Bruce Hamilton's Hobart party on October 13. The evening which Mr. Doggart spent with Dr. and Mrs. Archdall at their home on November 3 stands out as a treasured memory.

It was a joy to renew friendships with Dr. E. A. Brearley, Dr. W. M. C. MacDonald and Dr. Norman McA. Gregg. Dr. Gregg returned from his world trip shortly after the Melbourne meetings, leaving his wife and family for a further stay in England. It will be recalled that he was a particularly welcome overseas visitor at the B.M.A. Harrogate Meeting this summer. Dr. and Mrs. Darcy Williams were the very personification of kindness, and the writer is for ever indebted to them for bountiful help and attention. Both Mr. Doggart and Mr. Lyle found time to visit the building of the Medical Eye Service, where consultations at reduced fee are available on the clinic system. Dr. Darcy Williams' enterprise was largely responsible for the inauguration of this venture, which has proved a great boon to patients of moderate means.

Other friends to whose kindly welcome and generous hospitality in this thrilling city the writer would like to pay tribute are Dr. and Mrs. Cedric Cohen, who may rest assured of a warm welcome at the forthcoming International Congress, the Honourable and Mrs. Arthur Colvin, Dr. and Mrs. Clifford Colvin, Dr. and Mrs. Arnold Lance, Mrs. Claffy and her son Frank (a former house surgeon at the Central London Ophthalmic Hospital), and Father Frank Flynn, who loomed up in the dawn at Port Darwin with the same endearing smile as of old.

For every name that has been mentioned there are several times as many who contributed to the warmth of our welcome. Every invitation accepted was only one of a number which the swift passage of time rendered impossible of acceptance. Therefore many hospitable people worthy of mention must perforce be omitted, but they may rest assured that their generosity did not pass unnoticed. We who have been privileged to work as colleagues in peace and in war with men who came from all parts of Australasia felt certain that it would be a joy to enter their homes, and a 
source of stimulation to take a share in their professional conferences: but the event exceeded all expectations, so that we are profoundly indebted to the good folk of Australia, Tasmania and New. Zealand; and we are fortified in the conviction that we should mingle more closely with each other. Let fresh links be forged, and that right early.

\section{BOOK NOTICE}

Ophthalmic Medicine. By James Hamilton Doggart. Twentyeight coloured plates, 87 text figures. J. and A. Churchill, Ltd. 1949. Price, 32/-.

Only a select few in this country have attempted the difficult task of writing a text-book on the medical aspects of ophthalmology. In the wake of the late Sir William Gowers and Foster Moore comes J. H. Doggart with this admirable book on " Ophthalmic Medicine " succeeding by 24 years Foster Moore's second edition of Medical Ophthalmology, published in 1925. The qualities necessary to do full justice to this subject are considerable. The author of "Ophthalmic Medicine" has brought to this work the stored riches of his extensive clinical experience, a wide knowledge of his specialty and of its many contacts with the main body of medicine, the application of his philosophic mind to controversial matters, and an ease of expression in good English which makes the reader enjoy the book as an absorbing narrative. It is touched and enlightened here and there with advice which shows clearly the author's insight into the art, apart from the technique, of practising medicine. The book has achieved the author's purpose in its presentation of a comprehensive survey of the disorders and diseases of the eye in association with pathological changes in its adjacent'structures and in remote parts of the body. In this work he has correlated recent discoveries with the traditional aspects of medical ophthalmology.

The physician will be much helped by four well-written chapters on, the history of a case, symptoms, methods of examination and physical signs, and the ophthalmologist by the admirable dissertations on allergy; vitamin defects; inflammatory syndromes; focal, virus and fungus infections; metabolic disorders; and disturbances in endocrine function among other topics of general medical interest.

This book is a praiseworthy attempt to compress into 300 pages all that is sound in the teaching of ophthalmic medicine. It is well illustrated, and a fair bibliography is given at the end of every chapter. There is little to criticise adversely. It is evident that a mistake has been made in Plate XX, Fig. 2, where a tigroid 